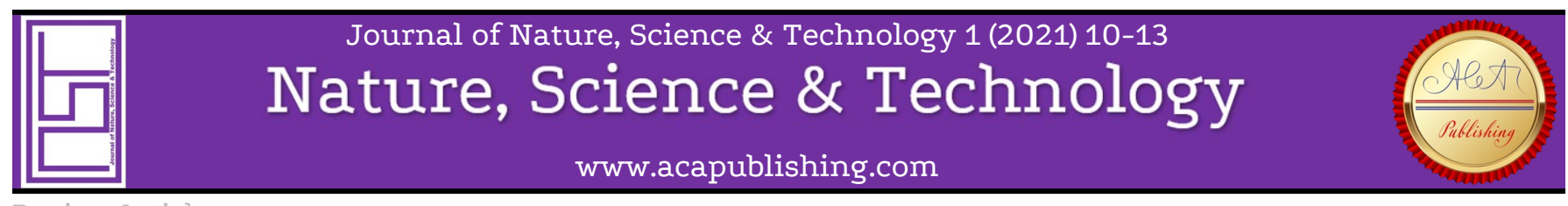

Review Article

\title{
Impact of COVID-19 on Higher Education in India: Lessons Learned and Mitigation Measures
}

\author{
C.P. Kaushal*, ${ }^{1}$, Vinayak Kaushal ${ }^{2}$ \\ ${ }^{1}$ MLSM PG College, Sundernagar, H.P., India 175018 \\ ${ }^{2}$ The University of Texas at Arlington, TX, USA 76019
}

\section{Keywords}

\section{COVID-19,}

Higher Education,

Online Learning,

India,

Pandemic

\begin{abstract}
Corona virus disease 2019 (COVID-19) is a communicable disease caused by a newly detected severe acute respiratory syndrome corona virus-2 (SARS-CoV-2). COVID-19 virus has spread all over the world including India. This corona virus pandemic has radically disrupted all the sectors including education sector, which affects the socio-economic conditions of the people and education system. This study is aiming to analyze the impact of COVID-19 on educational institutions, especially imparting higher education and related stakeholders till date, when the government has taken early decisions to breakdown the spread of virus among the community. The study is descriptive and analytical in nature where the information has been collected from the various official websites, newspapers, online news articles, and discussions with colleagues working in the higher education setup. This review study suggested some measures to overcome the situation such as special hygiene and health related measures like social distancing, using precautionary tools and equipment and some socioeconomic and technological measures such as economic supports for redesigning of the sector, public private partnerships in education system, digitization of the study techniques and educational infrastructure and use of Indian traditional knowledge. The higher education plays a key role for socio-economic development of the people in any country and with the implementation of these suggestive measures, the country will move forward and ensure the overall progress in education sector.
\end{abstract}

\section{Introduction and Background}

Corona virus disease 2019 (COVID-19) is a communicable disease caused by a newly detected severe acute respiratory syndrome corona virus-2 (SARS-CoV-2). The outbreak was first found in Wuhan, Hubei, China, in December 2019 (The first confirmed death was on 9th January 2020 in Wuhan), and was declared as a pandemic by the World Health Organization (WHO) on 11th March, 2020. WHO depicted countries to take immediate actions and scale up responses to treat, detect and reduce transmission to save the lives of people. As of December 2020, more than 79,031,545 cases of COVID- 19 have been found in over 200 countries and territories, resulting in around $1,736,582$ deaths and over 55,607,068 recoveries [1-3].

India has the world's largest democratic country after China with the 1.35 billion population [4-5] by means of the fundamental right of education to the people of India. Right to Education Act introduced as education is the fundamental right of every child in India [4-5]. In the Constitution of India, 86th amendment Act 2009 made in 2002 and inserted Article 21-A to provide free and compulsory education to al children of age group of six to fourteen years. By efficient use of technology in education system, India has been able to determine the longstanding apprehension between excellence and equity [6].

Even though, the education sector is suffering from various disparities like inefficient educational infrastructure, imbalanced teachers-students ratio, lack of modern technologies of teaching, lack of interest in education among the rural people, apathy and lethargy about the schooling etc. After 68 years of independence, India is not able to provide minimum level of education to its all citizen [6-7]. With these difficulties, now a days, the country is facing the worst problem of the novel corona virus (COVID-19) pandemic originated in Wuhan city of China. The World Health Organization declared that the outbreak of the pandemic has spread to more than 190 countries around the world. The pandemic has drastically disrupted all the sectors including education sector worldwide, which affects the socioeconomic conditions of the people. On this background, the study conducted and analyzed impact of COVID-19 and lockdown on education sector in India. Also discussed about some immediate measures to overcome the situation occurred in the sector [1-5].

The country is under the completely lock down of all the socioeconomic activities and movements of the people to protect human being from the community spread of the corona virus. All the sectors including educational institutions closed to more than a month and there is an uncertainty about when the education sector will reopen. This is a critical time for education sector in India because this is the time of various activities to be running within the sector like nursery school admission procedures to be started right now, board and university examinations of various academic courses, entrance exams for admissions in various universities all over the India and competitive examinations of several government and nongovernment departments are to be held during this period [1-7].

In the country like India, where about $42.1 \%$ of people are suffering from inequality in education [6], closures of educational institutions and lockdown will not only have a short-term impact on the continuity of edification for the young learners but also stimulate the comprehensive socio-economic consequences. The instant solution of corona virus is necessary or if like these days pass then closure of schools and colleges does not even have short term impact in India but can even cause far-reaching economic and societal consequences. Due to the closedown of educational institutions it is estimated to affect around 600 million learners across the world and more than 285 million young learners in India [7-8]. 


\subsection{How COVID-19 Spreads}

Literature evidence shows that the original source of the COVID-19 is from animals and recently the virus is spreading from human to human [5]. Recently there are no reasonable facts to identify how easily viruses are transmitted from person to person. However, the virus basically transmitted through respiratory droplets that human beings sneeze, cough, or exhale. The exposure to the virus and onse symptoms of COVID-19 is currently determined at between 2-14 days. At this stage, we aware that the virus can be delivered when those infected show flulike symptoms [7].

\subsection{Is COVID-19 Comparable to SARS Or the Seasonal Flu?}

The novel corona virus discovered in China is genetically closely related to the SARS-CoV-1 virus. SARS emerged at the end of 2002 in China, and it caused more than 8,000 cases in 33 countries over eight months. Almost one in ten of the people who developed SARS died. The current COVID-19 outbreak caused nearly 7,000 reported cases in China during the first month after initial reports (January 2020), with a further 80,000 cases reported worldwide during the second month (February 2020). Of these first 87,000 cases, around 3,000 died. The third month caused around 8,00,000 cases globally with death count touched to 45,000 . Cases are now being discovered across the globe [6].

\subsection{Facts About the Vaccine Against the COVID-19}

The development of vaccine took about an year and has been now recently distributed on the priority basis in the United Sates, the UK and India. Several pharmaceutical organizations around the globe are still working on vaccine candidates (different kinds of vaccines). It will, however, take months before the vaccine can be widely used all around the world [1-3].

\section{Objectives and Methodology}

This study is aiming to analyze the impact of COVID-19 on educational institutions, especially imparting higher education and related stakeholders till date, when the government has taken early decisions to breakdown the spread of virus among the community. The study is descriptive and analytical in nature where the information has been collected from the various official websites, newspapers, online news articles, and discussions with colleagues working in the higher education setup.

\section{Impact of COVID-19 on Higher Education in India}

Education is a key for socio-economic development of the people in any country. In India, there is a pressure on state's education departments and education sector that make education potential and accessible to every Indian with an issue of socioeconomic equalities and fairness. Under such situation, major impacts of new pandemic i.e., corona viruses on the education sector have enlighten and designated as follows:

\subsection{Impact on Students, Young Professionals and Parents [1-} 3]

- "Admission procedures of various schools, colleges and education institutions were delayed due to lockdown in all over the country.

Examinations of various academies, boards and universities were postponed or/and cancelled due to the protection measures from the pandemic.

Entrance exams for admissions in various universities research and educational institutions were affected all over India.

Competitive examinations of several government and nongovernment departments were exaggerated during this period due to the lock down and social distancing.
Indian students and parents who are planning for going to abroad for specialized studies are in panic conditions due to various problems related to the pandemic and it will be reduce the demand for admission in international institutions for higher education and specialized courses.

- Indian students who are studying in abroad are in fear of pandemic of corona virus because most of countries affected by COVID-19 and possibility of no preference to foreign studies in future.

- Visible impact can be seen on paying capacity of several parents to the private educational institutions due to the no ability to spend.

- Due to the economic losses of education sectors, students and young professionals may face difficulties in placements, trainings, apprenticeships, on campus and off campus interviews, internships and jobs."

\subsection{Impact on Educational Institutions [1-3]} "Some faculties and employees in private education sector
may face the obstacle of job losses, salary cuts; bonuses and increments could also be postponed or reduced.

- Schools, colleges and other institutions and universities may face shortcoming of slowdown in admissions, internships, trainings, apprenticeships, and placements of the students.

- Education sector may face the problems of lower fee collection which can creates complications to run and manage the institutions.

- Infrastructural development, teaching styles, appraisal techniques and quality of education may affect due to the situations faced by the education systems.

- $\quad$ Some educational institutions may cut the jobs or reduce the workforces because of economic stagnation situations may accurse in the sector.

- Some institutions may completely close due to the economic slowdown and recession in the sector.

As per the Centre for Monitoring Indian Economy, unemployment shot up estimated as $8.4 \%$ in mid- March to $23 \%$ in early April and the urban unemployment rate to $30.9 \%$ [4]."

\section{Suggestive Mitigation Measures}

To mitigate the effects of pandemic, necessary and immediate measures are required in this time of dilemma. Quality education and effective learning techniques are needed for the overall development of students. Expansion of capacity-building, skill development, practical knowledge enhancement, motivational programmes, use of modern tools and techniques and other welfare programmes are required for enrichment of young minds. The review shows that various tools, models and technologies of virtual classes and online education has played a key role in educating the future generations and created the revolution in Indian higher education system and it is widely accepted by all the faculties and students due to the crisis of COVID-19. Such programmes will be helpful for student's overall improvement in terms of employability, efficiency, health, and wellbeing in near future [1-8].

Some important suggestive measures are discussed as follows [1-10]: 


\subsection{Special Hygiene and Health Related Measures}

"Regular cleaning and sanitization of school, colleges, universities, premises, offices and surrounding areas near the educational institutions.

This virus generally spread through plastics, steels and any type of material and metals. So regular sanitization and cleaning of these equipment and tools are most important

Spread of the virus experienced through social contacting Keeping social distance and avoiding participation in large gatherings is the best cure for controlling the spread of the virus

Frequent practice of washing hands with soap up to 20 seconds is the best way to protect ourselves from the virus. Using alcohol-based sanitizers also suggested to clean the hands

Using infection control and prevention materials like gloves, masks, gowns, goggles, head cover, rubber boots etc. are suggested by world health organization for covering the head, face and the body.

- $\quad$ Covering nose and mouth with paper napkins and cloths while sneezing and coughing to control the spread of the possible diseases.

- Regularly cleaning of abovementioned reusable preventive materials and properly disposing of unusable materials for controlling the infection spread

- Contacting to a doctor if anybody observing the fever, cough, difficulty in breathing and making calls on state helpline numbers of Ministry of Health and Family Welfare

Downloading the Aarogya Setu mobile application developed by the Government of India to connect with people and inform about the risks, best practices and relevant advisories to containment of corona virus [1-5]."

4.2.

\section{Socio-economic and Technological Measures to Reshape} the Education Sector

"Public private partnership in education sector for development of the education system in terms of excellence and quality improvement

- Economic support to the sector from private and government organizations to resolve the recession crisis and development of the cost-effective environment

Infrastructural development in terms of modern tools and techniques, safe and hygienic buildup, and nontoxic atmosphere of the education sector

- $\quad$ Providing supports for digitization of teaching techniques and education system, internet infrastructure development, trainings, and capacity- building programmes to teachers for developing the skills

Quality education and effective learning techniques such as expansion of capacity-building, skill development, practical knowledge enhancement, motivational programmes, use of modern tools and techniques

- Motivational and welfare programmes for students to improve their employability, efficiency, health, and well-being.

Use of modern technologies like online teaching methods study from home, virtual classroom techniques, e-learning and distance learning programmes.

As considered globally, the Indian traditional knowledge system may play an important role to redesign the education system worldwide. So, this can be integrated with the convention of current situation. Such as ayurveda, agriculture, architecture, hydraulics, ethno-botany, Indian medicinal studies, metallurgy and yoga should be integrated in educational curriculum to build up a superior foundation of humankind and young futures of the country [1-5]."

\subsection{Limitations}

Low-income government and private schools, colleges and other educational institutions may not be able to adopt modern tools and techniques such as e-learning, online teaching methods, study from home, virtual classroom techniques due to poor economic conditions. Poor socio-economic conditions may not allow people to develop and use the internet infrastructures in rural areas. Some students, parents and even educational institutions may afraid and discouraged to reshape of their educational slowdown conditions because of unprovoked apprehension of COVID-19 pandemic again [18].

\section{Results and Discussions}

This review study suggests that the government and relevant institutional bodies have been performing well for the safety of their stakeholders at early stage when COVID-19 was declared as Pandemic. Every Institutional body started making their stakeholders aware about precautionary measures to be taken to prevent themselves from the spread of corona virus. The Government declared lockdown throughout the country which helps to breakdown the spread of corona virus among the people. The Department of Higher Education under the Ministry of Human Resource Development (MHRD)issued the letter which suggests the stakeholders for the use of digital learning platform during quarantine time so that learning among students do not stop. Department of Higher Education under MHRD also suggested the social distancing measures for prevention of their stakeholders and informed them to work from home wherever required [1-5].

The Central Board of Secondary Education (CBSE) has informed their teachers to use quarantine time for preparation of lesson plan, use of digital platforms for self-development purpose, designing online assessment, etc. The University Grant Commission had shown concern towards the Hostel students during this pandemic period. Concerning on this issue the University Grants Commission (UGC) has requested to all the staffs (i.e., deans, wardens, and other staffs) to take due care of their hostel students. The Government and relevant governing authorities have proved that the safety of their stakeholders is their priority [5-7].

The educational institutions need to implement their curriculums in such a way which makes students aware about the pandemic diseases like coronavirus, swine flu, and so on which will be helpful for the students who are the future of our country, and, they would know how to tackle with such disastrous situations [8].

Till the date there has been no Antivirus to kill this disease except the Social Distancing to avoid the spread of COVID-19. So, keeping a distance and being at a home, as suggested by our governments, is the only cure for such pandemic disease [9-11].

The awareness must be created for preventive interventions such as the use of sanitizer for cleaning hands, use of mask, avoid handshake, using handkerchief over mouth while coughing/sneezing and follow other guidelines given by the relevant authority, which will help in reducing the transmission of the disease from one person to another.

Maintain social distancing to breakdown the spread among others because one affected person can cause spread of corona virus to whole of the society. It is also suggested to not to go outside the home Unless it is very important work which, in turn, helps us keep safe and secure at home with your family [12-14].

The Institutions are suggested to pay salary to their unaided staffs on time so that; they can manage their expenses during lockdown period. Teachers are suggested to be in touch with their students and keep them motivated during this pandemic lockdown period [15]. 
It is suggested that the exams should not be cancelled out completely instead, the exams should be held online so that the results of students could be marked as per their performance. Also, this would encourage students to keep learning and revising their own subjects regularly. The Educational bodies are doing well for the development of their stakeholders but also, they are suggested to keep in touch with their staffs to keep them motivated, so that they feel secure about their respective jobs and work enthusiastically for the institution during lockdown period [1-5]

\section{Conclusions and Recommendations}

The review study concluded that the education plays an important role for socio-economic progress of the people in any country. In India, there are large gaps in the education sector and now-a- days country is facing a dilemma of new novel-corona virus pandemic. The lockdown circumstances may affect the socio-economic conditions of the people and educational institutions of the country. To mitigate the effects of pandemic, necessary and immediate measures are required in this time of predicament. Special hygiene and health related measures and some socio-economic and technical measures have been suggested in this study to overcome the crisis and reshape the education sector. Successful implementation and enforcement of these suggestive measures shall help the education sector to move forward and ensure the overall progress.

\section{Declaration of Conflict of Interests}

The authors declare that there is no conflict of interest. They have no known competing financial interests or personal relationships that could have appeared to influence the work reported in this paper.

\section{References}

[1.] Jena P. Impact of Pandemic COVID-19 on Education in India International Journal of Current Research (2020), Vol. 12, Issue, 07, pp.12582-12586, July, 2020

[2.] Bokde V, Kharbikar, HL, Roy, ML, Joshi, P, and Ga A. Possible impacts of COVID-19 pandemic and lockdown on education sector in India. (2020). Food Sci. Rep, 1-7.

[3.] Gupta A, \& Goplani, M. Impact of COVID-19 on Educational Institution in India. Purakala Journal U (CARE Listed), 31(21), (2020).

[4.] Premlakshmi, K. Right to Education and Common School SystemPerception among Teachers. Journal of Educational Research (EDUSEARCH). (2011). Vol.2, Number-2, 106-111.

[5.] Right to Education Act. Department of Elementary Education and Literacy, (2009). MHRD, Government of India, New Delhi.

[6.] Shenoy, V, Mahendra, S and Vijay, N. COVID 19 - Lockdown Technology Adaption, Teaching, Learning, Students Engagement and Faculty Experience. Mukt Shabd Journal. (2020). IX (IV) APRIL/2020. pp. 698-702

[7.] Singh A. Challenges in Indian Education Sector International Journal of Advanced Research. (2015). Communication and Management. September. 2015;1(3):54-58.

[8.] Barman P. and Mandal S. Right to Education Act and its practical implementation in school education: An Attitudinal Study at Teachers Level September 2015 In book: Education in India: Issues, Prospects and Challenges Publisher: New Academic Publishers, New Delhi

[9.] Census of India Report. Registrar General Census Commission of India. (2011).

[10.] Fernandes A. COVID-19: A second wind for higher education in India. In COVID 19 India exclusive. (2020). Compiled by Ramanujam, P. QS-COVID 19 report March, 2020. pp. 1-10
[11.] Human Development Report. United Nations Development Programme (2014). One United Nations Plaza, New York, NY 10017.

[12.] Coronavirus. In World Health Organization. Retrieved March 27, 2020, from https://www.who.int/healthtopics/coronavirus\#tab=tab_3

[13.] Coronavirus disease (COVID-19) advice for the public. In World Health Organization. Retrieved Oct 2, 2020 from https://www.who.int/emergencies/diseases/novel-coronavirus2019/advice-for-public/

[14.] COVID-19 INDIA. In Ministry of Health and Family Welfare, Government of India. Retrieved Oct 1, 2020, from https://www.mohfw.gov.in/

[15.] Kimberling C. Coronavirus presents new challenges and opportunities to higher education. In The Hill. (2020).

\section{How to Cite This Article}

Kaushal, C.P. and Kaushal, V. Impact of COVID-19 on Higher Education in India: Lessons Learned and Mitigation Measures, Journal of Nature, Science \& Technology, 1(2021), 10-13.

https://doi.org/10.36937/janset.2021.001.002 